\title{
Puja Birla: Mongrel Prose by the Puristically Challenged
}

For the past five years, right around essay submission time, I have tried to drill a basic writing template into my students' brains: make sure your first 30 words draw me into your essay; don't write in lecture mode, write in conversation mode; attribute and substantiate; maintain tense unity; avoid grammar and spelling errors. There have been varying degrees of success-starting from a D-, crowding mostly between $\mathrm{C}+$ and $\mathrm{B}$, and a couple reaching up to an $\mathrm{A}$. The mistakes and inadequacies have been common enough that I could copy and paste comments from one essay on to the next, if I wanted to.

Many of these students are vastly different during class discussions, making more astute observations while talking and responding than while writing 1,500 words over a two-week period. Though I agree that speaking and writing are different skills and both need to be developed, my problem is with the straitlaced way we define praiseworthy critical writing, starting from freshman Comp and going all the way up to the completion of a $\mathrm{PhD}$ dissertation. I don't think the basic writing model I try to drill into my students' heads is the only acceptable one or even the best. I'm secretly pleased with students who show enough chutzpah, defy my suggestions, and create their own standards of articulating a critical argument.

Unfortunately, a majority of them flop like fish out of water after the first paragraph or so. I give them more time, though I'm not supposed to; I write some of their sentences but that's a no-no too. I have justified this cheating because, in my heart, I side with the rule breaker, the recalcitrant, 19-year old renegade who thinks she can trailblaze her way into an entirely original essay in an "Introduction to Literature" class; because surely there can't be just one way of writing an ' $A$ ' grade essay in an "Introduction to Literature" class.

I side with her because I have found myself defying similar requirements in my graduate classes-creative writing and translation workshops that, instead of celebrating subverting language rules and routinely used word clusters, seem to want to preserve them like fossilized relics of an age when English writing was done only in one particular way and anyone not writing that way was considered unaccomplished; as if one kind of English was better, more superior, than another. At the same time, some my comments on student papers make me sound like a hypocrite: I urge them to think creatively-"don't economize with your grey cells"-yet I seem to pound them on the head with a saucepan, (think Tom-and-Jerry cartoons) for straying too far from the acceptable template.

Why do we hold on so tightly to the notion that language is fixed? That it is pure only when used in a particular form or a specific idiom, and discard any other paradigm that questions, challenges the so-called standard? Why is scholarship deemed worthy only when it uses a certain type of obscure verbosity?

As a student, this blinkered attitude hit me the hardest in translation workshops-classes that professed to accept the eccentric accents possible in writing in English, or any language for that matter. Much to my confusion, dismay, and finally, indifference-in that order-I discovered in my workshop classes that although we were all wordsmiths, writers and translators, translating from different languages 
into English, the point of reference for most of my colleagues was an American English, which they identified as their first language. It was the status of being native speakers of (American) English that gave them a stamp of authenticity. One is most proficient in one's mother tongue, or so it seemed in these classes. At the cost of endangering my perceived sense of reasonableness, I have to say that this first-language-second-language division seems to me to be a favorite taxonomic diversion in humanities departments but it doesn't serve any real purpose. Hindi is my first language, but that is no help. There are some things I can't do in Hindi and there is stuff for which English falls short. The two languages are not in a hierarchical relationship. They are in conversation with each other. Reason and logic flow better in one; friendship, tenderness, and banter in another. Perhaps, I've doomed them to hierarchy already by assigning reason to one and tenderness to another, although that hierarchy exists only if one set of responses is preferred over another.

But back, now, to my dismay. After being asked repeatedly what my first language was, I chose Hindi. Before becoming a part of the academia, this question hadn't even entered my mind but once the choice was made, it immediately gave me a minority status in our little menagerie of translators. I was one of two whose first language was not English, and by extension, I couldn't be trusted to have knowledge of Standard English. (American only; can Indian English really be considered standard if a majority of the class doesn't have an ear for it?) We read reams of scholarship that conceived of the ideal translator as someone who translated into her first language and not from it. Since the rules of grammar of her first language would be hardwired into her brain, all possibility of the translation sounding 'odd' would be avoided. In other words, the literary catastrophe where a translation reads like a translation would be averted; the reader's pleasure would continue unencumbered. The assumption being that you can't sound 'odd' when translating into your first language.

To be an ideal translator, as per these philosophers, I should be translating into Hindi and not from her. But why? Why should the ideal translator translate into her first language and not from it? And what if there are two first languages, like identical twins, same and yet different?

My 'experiments' with writing and translation have seemed 'strange' even 'disturbing' to many across the numerous workshop tables I have sat around. It is difficult to gauge how aware we were in those classes of our own hypocrisy as literary translators when, on the one hand we proclaimed a desire, actually a determination, to retain the rhythms and idiosyncrasies of the original language, while on the other, we wanted to 'smoothen' the translated language so that it wouldn't 'frighten' or 'alienate' the (American) reader. More practically speaking, we wanted to guard against potential rejections from editors who wanted the prose to be devoid of any accent. Was this desire simply a cosmetic attempt, window dressing, the right amount of exotic titillation to lure the reader instead of frightening him away? Dish up ethnic food in restaurants to make them more popular with the non-ethnic crowd? Make the food too authentic and you may end up with the ethnics themselves, and a much lower profit margin. I have no problem with ethnic restaurants that cater mainly to a non-ethnic crowd. Let them have their saag paneer as long 
as it's not The Saag Paneer, and I'll get mine some place else.

It was only recently that my father figured out the Devnagri function on Gmail and wrote me an email in Hindi. It is the longest personal email I've ever received from him — six lines of the tightly packed Devnagri script, a blue-ribbon example of 'show don't tell.' In those six lines, there is description, action; a scene, peopled with others who enter and exit. It is a little sentimental, tinged with humor, and loving. It addresses me by my 'pet' name_-Bubble, as opposed to my 'good' name-Puja. It does what good writing is supposed to do: it moves the reader.

Dad rarely displays emotion in his writing, prone as he is like many middle-class Indians of his generation, who mastered English as a third language at the dual altars of Reader's Digest and Wren \& Martin English Grammar and Composition, to use that peculiarly formal and archaic register that often encourages its practitioners to sign off with a chivalrous, 'Kindly do the needful.' English is the language of his public identity, business, and reasoning. His linguistic brain is not wired to start a letter in English with 'Bubble' because that is not my name for the world; 'Puja' is more compatible. It sounds right. But Hindi, ostensibly the language of his private emotional self, is not so easily contained especially when he's writing me. She tiptoes into his English sentences, forcing them to be longer than what P. Wren and H. Martin would have advised, occasionally playing havoc with tenses especially when he's excited, converting verbs into nouns, imposing her syntax on his colonial tongue. And yet, that writing moves me, the reader, in a way that no other writing from him has in the past. It is a piece that accomplishes what it sets out to do. Even after 45 years of writing and communicating and reading in English, Dad's diction continues to sound a little accented to me, as if not just Hindi but other language ghosts are exerting a subtle invisible influence.

I used to think I was beyond the fold of Hindi's influence. Unlike Dad, I had been educated in an English-medium 'convent' school; I pronounced my ' $z$ 's' and 'sh's' correctly; I enjoyed English movies and had been a fan of the early Michael Jackson. English would be my source of power, my vehicle of global movement. It is. I wouldn't find space in this journal if I didn't know how to appear coherent in this language. It would be difficult to find space in this country, for that matter. And yet, I identified Hindi as my first language when I was asked the question, an identification that marks me as different, foreign, and less powerful in many situations.

I sound strange to people in this country, the way Dad does occasionally to me. But his quirky diction is so much richer and more interesting to hear; unique as if his cocktail idiom is his signature. Why can't we encourage writing that takes into consideration more of our socio-linguistic background? Critics, who lament the current condition of reading and writing among high school and college students, would say that I favor the 'dumbing down' position. I don't think it is dumbing down as much as it is allowing, encouraging even, another way of expressing understanding. When most of us teach a book, we have read it at least once before; have had a chance to think about it longer; and have had some basic training in thinking and talking about literary texts in general that may, if nothing else, at least sound intelligent. Our freshmen and sophomore students don't have that advantage, even when they are given two weeks to write 1,500 words. As a reader, I want to engage with the text on my 
terms. Whenever I don't have that freedom, reading seems a chore. It is unfair to expect my students to engage with the reading list on some arbitrary standard that demands a single set of vocabulary from all 24 of them. Does our writing always have to maintain one style throughout a particular piece of text, instead of having a motley orchestra of registers and accents? Every piece of writing may not need that but it would be a shame to discourage its appearance in texts that can accommodate such diversity. Who knows, we might actually increase our readership base by allowing more people in rather than excluding them from articulation.

I get it that a certain standard of writing has been established, deemed appropriate for certain disciplines but can we not reassess some of these standards? Need we impose one standard on all situations? In the Fiji Islands, the descendants of Indians who were brought in as 'coolies' or indentured laborers, are convinced that the language they speak-Fiji Baat-is a vulgar and bastardized version of the 'shuddh' 'pure' Hindi that is spoken in India. This idea of 'shuddh' Hindi, of course, doesn't exist outside of government forms. No one talks like that in India, and yet the Indo-Fijians continue to use 'shuddh' Hindi in official discourse, radio and TV news broadcasts, and even entertainment programs, denying Fiji Baat any public life or record. 'Shuddh' Hindi has been designated as linguistically authentic even though the generations that came through indenture and their descendants have never really spoken the language. This preoccupation with language purity is more like linguistic schizophrenia.

Fiji Baat developed historically in the 'coolie' quarters during indenture, accruing rules and vocabulary as it began to ferry to and fro among the 'coolies' from different parts of the subcontinent, evolving a broad enough idiom to express the range of emotional anguish, physical pain and mental abuse the 'coolies' underwent at the hands of the colonial overseers. Today, a vast majority of Indo-Fijians are convinced that Fiji Baat simply serves as a reminder of the time when Indians in Fiji were being beaten, raped and murdered; language has become a souvenir of shame, and the only way to erase that shame is to obliterate the language, especially from public record; to move on and move away from Fiji Baat. In all creation myths of the myriad cultures of this world, is there a single one that surmises we didn't originate from divine wombs? Between associating with a language that prompts memories of an historical and humiliating past, and another that is ahistorical, disconnected but golden in its primogeniture, the Indo-Fijians have decided to choose a tongue that is regarded as the daughter of the language of gods. Is that the paradigm then that we must emulate?

Perhaps we need to rethink the way we want to teach and learn about using language in our education systems. Is it more important to articulate or more important to articulate a certain way? This is not a case against specialized language, I'm all for it. I'm just not so confident that it is what we need at 18 , or that it remains the only yardstick to test an individual's intellectual muscularity.

Instead I think we must make space for all accents of writing, especially when the subject itself is writing. The fact that Fiji Baat has no place in the public life of Indo-Fijians is not a situation to be proud of. It leads to a synthetic and monolingual world, and we must actively resist such an outcome. 
Puja Birla has lived (or continues to do so) in Jamshedpur, Bombay, Madras, Delhi, Iowa City and Washington, DC. She has taught literature and creative writing to American undergraduates, mathematics and language to Indian elementary school students, and is currently learning how to conjugate Spanish verbs. She received a double M.F.A. in Nonfiction Writing and Literary Translation from the University of Iowa, and has some ambition of being a published author.

\title{
Samuel Gerald Collins: Encouraging the Secret Vice in Anthropological Writing
}

\begin{abstract}
"Is it a Memorial about his own history that he is writing, aunt?" "Yes, child," said my aunt, rubbing her nose again. "He is memorializing the Lord Chancellor, or the Lord Somebody or other-one of those people, at all events, who are paid to be memorialized-about his affairs. I suppose it will go in one of these days. He hasn't been able to draw it up yet, without introducing that mode of expressing himself; but it don't signify; it keeps him employed."

In fact, I found out afterwards that Mr. Dick has been for upwards of ten years endeavoring to keep King Charles the First out of the Memorial; but he had been constantly getting into it, and was there now.
\end{abstract}

-Charles Dickens, David Copperfield

In David Copperfield, Dickens introduces the comic figure of "Mr. Dick," whose efforts to write a contemporary memorial are continuously hampered by his inability to not write about the severed head of Charles the First. For me, the challenge of teaching students to write anthropologically bears an eerie similarity to Dickens's Mr. Dick, fruitlessly trying to keep the severed head out of it. As in any writing, there are lots of "heads" to be kept at bay, including the many-headed hydra of orientalism, racism, androcentrism, together with the usual suspects of specious generalization. In fact, one can see the success of ethnographic writing as in some ways depending on its exclusions, the kinds of choices people make when analyzing their fieldwork between what is important and what is unimportant - in other words, deciding which differences "make a difference" (to paraphrase Gregory Bateson) and cutting out the rest. Or, to put it another way, the work of ethnography is very much premised on what Michel Serres has called "parasite" writing, where anthropologists either

incorporate the parasite into their midst - and thereby accept the new form of communication the parasite inaugurates - or they act together to expel the parasite and transform their own social practices in the course of doing so." (Brown 16-17)

Going through fieldnotes and generating something meaningful from all the effluvia is just such a struggle.

But there are other things the ethnographer generally seeks to exclude - things J.R.R. Tolkien refers to in a well-known paper delivered at a 1931 Esperanto conference as the "secret vice." For him, this meant the fascination with the creation 